OPEN ACCESS

Edited by:

Helga Kristin Hallgrimsdottir, University of Victoria, Canada

Reviewed by:

Ivar Jonsson,

Østfold University College, Norway Slawomir Banaszak, Adam Mickiewicz University, Poland

${ }^{*}$ Correspondence: Jón Ólafsson jonolafs@hi.is

Specialty section: This article was submitted to Political Participation,

a section of the journal Frontiers in Political Science

Received: 20 October 2020 Accepted: 08 March 2021 Published: 07 May 2021

Citation:

Ólafsson J (2021) The Case Against Leaders: A Moral Reading of Geir Haarde's Conviction for Negligence of Ministerial Duties. Front. Polit. Sci. 3:619719. doi: 10.3389/fpos.2021.619719

\section{The Case Against Leaders: A Moral Reading of Geir Haarde's Conviction for Negligence of Ministerial Duties}

\author{
Jón Ólafsson* \\ Department of Comparative Cultural Studies, University of Iceland, Reykjavik, Iceland
}

In the aftermath of the Icelandic economic crisis of 2008 Iceland's former Prime Minister Geir Haarde was convicted for negligence of his constitutional duty to consult with his ministers on measures to prepare for the coming crisis. The court ruled that there was sufficient information available to the government to conclude that there was real danger of a major banking crisis in the months preceding the crisis. Mr. Haarde was the only head of government to be convicted in the aftermath of the Financial crisis. His indictment and conviction was hotly debated in Iceland where many people considered the process unfair, primarily because Mr. Haarde was the only minister indicted by Parliament for negligence of duties although a Special Investigative Commission appointed by Parliament had recommended indicting other ministers and officials as well. The paper reviews the case against Haarde and the public reaction to it. It is argued that the majority of judges on the special court which convicted Mr. Haarde used the constitutional clause on the duty to conduct ministerial meetings to present a more wideranging condemnation of Haarde's failure to deal with and acknowledge the threats Iceland was facing. Public opinion changed over time: When the Parliament began its consideration of whether to indict former ministers surveys showed an overwhelming majority favoring indictments, but limited confidence that anyone would actually be indicted. When proceedings against Mr. Haarde started public support was much less. After the conviction opinion polls have shown growing doubts about the special court itself. The whole case is an interesting example of the elusiveness of accountability: The paper argues that a thoroughgoing moral reading of Mr. Haarde's conviction reveals a more damning analysis og his actions (and lack of actions) than has generally been acknowledged by political leaders and in public debates.

Keywords: ministerial accountability, crisis, constitution, Geir Haarde, Iceland

\section{INTRODUCTION}

In the aftermath of the Icelandic economic crisis of 2008 Iceland's former Prime Minister Geir Haarde was convicted for negligence of his constitutional duty to conduct ministerial meetings on measures to prepare for the looming crisis. In its verdict the Court of Impeachment ${ }^{1}$, which tried

${ }^{1}$ Icel. Landsréttur. In English this special court is sometimes referred to as "National Court" but in this paper I will use the term "Court of Impeachment". Although this is a slightly misleading translation - since the court tries not only sitting ministers it has been used more broadly, including in proceedings in the ECHR. 
the case, concludes that for most of 2008 the Icelandic government was aware of the danger of a very serious financial crisis striking in Iceland. It therefore could have reacted to this situation in a more systematic and decisive manner in particular to form policy on government level, which it failed to do (see Bragadóttir, 2017; see also ECHR 66847/12, 2018).

In September and October 2008 three Icelandic banks with large international operations became insolvent. Their bankruptcies spurred the deepest economic crisis since Iceland became a sovereign state 90 years before. In hindsight however, their downfall had obvious reasons. The three banksLandsbanki, Kaupthing, and Glitnir-had grown rapidly and overextended their portfolios. That made them extremely vulnerable to the consequences of the international financial crisis. "Vast complex cross-ownership structure of Icelandic firms" still increased this vulnerability and as a consequence they all went bankrupt in a period of just a few days in October 2008 (Johnsen, 2015, p. 52, 171). It is widely acknowledged that if the opportunity had been used between 2006 and 2008 to reduce their portfolios, change ownership structure or move their operations fully out of Icelandic jurisdiction, the consequences of the international crisis would have been much milder for Icelanders. The crisis was certainly a part of an international financial crisis, but the enormous size of these three Icelandic banks, nine times larger than the Icelandic economy, made things worse in Iceland than in most other countries that suffered from the international crisis (see Rannsóknarnefnd Alpingis, 2010; Bergmann, 2014). Mr. Haarde was also the only head of government to be convicted in its aftermath for failing to deal with the crisis. His indictment and conviction were hotly debated in Iceland where many people considered the process against him unfair. A few weeks before the trial a survey showed the public split in equal halves between supporters and opponents of Mr. Haarde's prosecution (Djóðarpúls Gallups, 2012). No other government ministers were prosecuted although a Special Investigation Commission appointed by Althingi, the Icelandic Parliament, to investigate the events and causes that led to the collapse of the Icelandic banks, had concluded that some other ministers and officials had been criminally negligent (Special Investigation Commission, 2010a, p. 18).

This paper reviews the case against Mr. Haarde. It is argued that the majority of judges on the Court of Impeachment used the constitutional clause on the "duty to conduct ministerial meetings to discuss important state matters" to present a wideranging assessment of Mr. Haarde's failure to deal with and acknowledge the dangers faced by the Icelandic state. The paper argues that the verdict, although based on a narrowly legal interpretation of the Prime Minister's actions, can also be read as a broad condemnation of governmental lack of credible action to protect the country against the imminent crisis, making the Prime Minister accountable for a more general and systemic failure to acknowledge and react to unmistakable signs of great danger-until it was too late.

Public opinion of the case against Haarde changed over time: When the Parliament began its consideration of whether to prosecute former ministers and officials in 2010, surveys showed an overwhelming majority favoring prosecution, but in public discussion doubts were also voiced about the "steadfastness" of the Parliament to actually go so far as to indict politicians for their decisions (Blöndal, 2010; Pjóðarpúls Gallups, 2010). When Mr. Haarde was singled out for prosecution, support markedly lessened and when proceedings against him started doubts about the wisdom of prosecution became predominant in public discussion ${ }^{2}$. After the conviction opinion polls have shown growing doubts about the Court of Impeachment itself (Deliberative Poll, 2020, p. 44-52).

Mr. Haarde's case shows how accountability can become elusive: The examination of the verdict presented in this paper reveals a tension between a political, legal and moral reading of the case. The moral (rather than the legal) reading of the indictment already raises the deeper political question: What circumstances justify going beyond political accountability of elected officials serving in leadership positions? When is negligence serious enough for a leader of government to not only lose support and possibly be removed by voters and peers, but to face a criminal conviction? How should criminal prosecution of sitting and former ministers for their decisions in office be understood? What I aim to do in this paper is first, to showwithout addressing their legal aspects-why these questions, are essentially moral questions and second, suggest some answers to them based on the case of Mr. Haarde.

\section{A BRIEF OVERVIEW OF THE CASE}

Geir Haarde was Prime Minister of Iceland from 2006 to 2009. He was indicted 10 May 2011 for "offenses committed purposely or with gross negligence during the period from February 2008 through the beginning of October the same year" by a prosecutor appointed by the Icelandic Parliament (Althingi) (Saksóknari Alpingis, 2011). The indictment followed a parliamentary resolution passed on 28 September 2010, in which Althingi decided to initiate criminal proceedings against Mr. Haarde (Parliamentary Resolution, 2010). At the same time Althingi voted not to prosecute three other ministers who had served in Mr. Haarde's government, the former Minister of Finance, former Minister of Foreign Affairs and the former Minister of Banking and Trade (Tillaga til pingsályktunar um málshöfoun gegn ráðherrum, 2010). In voting on the resolution, the Parliament made use of its constitutional powers to prosecute ministers (and former ministers) for violations of the law on ministerial accountability. Such cases are tried in the Court of Impeachment (Constitution, 1944, art. 14; Act on Ministerial Accountability, 1963).

\footnotetext{
${ }^{2}$ Such doubts were expressed quite forcefully by former leaders of the Independence party, Mr. Haarde’s predecessors, Porsteinn Pálsson and Davíð Oddsson. See Pálsson (2010), Reykjavíkurbréf: Mál lagt í dóm (2012). "Reykjavíkurbréf" has no byline but is presumably written by Davíð Oddsson, editor in chief of Morgunblaðið, a leading daily newspaper in Iceland. Pálsson led the liberal-conservative Independence party from 1983 to 1991 and was Prime minister 1987-1989. Oddsson led the party from 1991 to 2005 and served as Prime minister of Iceland 1991-2004).
} 


\section{The Indictment}

The indictment listed six counts which detail Mr. Haarde's alleged failures to adequately react to signs indicating that the Icelandic economy was in great danger due to the emerging international crisis and the oversized portfolios of the three aforementioned privately run Icelandic banks. The first five counts were for violations of the law on ministerial accountability. Two of them were general and focused on a failure to initiate legislative and governmental measures to "avoid foreseeable danger" and for the failure to properly explore and analyze the financial risk faced by the State. Three counts were more specific and dealt with alleged failure to make proper effective use of a consultative government group put together specifically to analyze and monitor the economic outlook; failure to take the initiative to reduce the size of the Icelandic banks that later collapsed and a failure to follow up upon work to transfer savings accounts created by one of these banks, to a subsidiary to ensure that the Icelandic state could not be held liable for insurance payments to accountholders abroad when the bank collapsed.

The sixth count was for a failure to convene ministerial meetings on policies to avert or prepare for the crisis in the period of February to October 2008 in violation of article 17 of the Icelandic constitution (see ECHR 66847/12, 2018, \$ 8). Mr. Haarde was convicted on the sixth count, the first two were dismissed and he was acquitted on the remaining three.

\section{The Court}

The Court of Impeachment considered a request for dismissal of all counts by Mr. Haarde and dismissed the first two, 1.1 and 1.2, on 3 October 2011, but upheld the rest (IRR13110314/3.11, 2011, p. 25). The trial was conducted in public from 5 to 16 March 2012 and a verdict passed 23 April in which the defendant was cleared of three of the four remaining counts, but found guilty of count 2, i.e., of having failed to hold the constitutionally required ministerial meetings, which also constituted a violation of section 8(c) of the Ministerial Accountability Act (IRR13110314/3.11, 2012, p. 379-398).

The Court of Impeachment consists of 15 judges. Eight are appointed by Althingi, five are the longest sitting justices of the Supreme court, including the president of the court; the professor of constitutional law at the University of Iceland and the presiding judge of the Reykjavík district court (Act on the Court of Impeachment, 1963). In Mr. Haarde's case the court split. A minority voted to clear him of all counts (IRR13110314/3.11, 2012, p. 399-429). In my discussion I focus on the majority opinion.

Geir Haarde appealed the case to the European Court of Human Rights on 17 October 2012 arguing that his prosecution and trial had violated articles 6 and 7 of the Human Rights Convention. The ECHR delivered its verdict on 23 February 2018 and rejected Mr. Haarde's appeal, ruling that the Human Rights convention had not been violated in his case (ECHR 357, 2017).

During the trial and especially after the verdict was passed, the public reaction to Mr. Haarde's prosecution was mixed. In media discussion several different views were frequently expressed against the case. The main and most frequent complaint was that it would rather deepen divisions in Icelandic society than help heal wounds caused by the crisis (Pálsson, 2010). Some commentators found it unfair to prosecute only Geir Haardeother ministers were equally guilty of negligence as he was, it was argued (Ógeðfelld afgreiðsla, 2010).

\section{Investigating the Crisis}

A Special Investigation Commission, which Althingi appointed to investigate the causes of the financial crisis in Iceland in 2009, had also come to the conclusion in its report that the former Minister of Banking and Trade and the Minister of Finance, probably were guilty of criminal negligence (Special Investigation Commission, 2010a, p. 18). A parliamentary committee which analyzed the findings of the Commission recommended that these three ministers be prosecuted and the former Minister of Foreign affairs as well (Skýrsla pingmannanefndar til að fjalla um skýrslu rannsóknarnefndar Alpingis, 2010). When Althingi voted on the issue however, a majority was opposed to prosecuting the other three Ministers and voted to prosecute only Mr. Haarde (Parliamentary Resolution, 2010).

\section{The Case and the Crisis}

Mr. Haarde's supporters, as well as he himself, reacted with great embarrassment and even contempt to the verdict, which Mr. Haarde described to journalists as "ridiculous" (Pólitískur pefur af dómnum, 2010). An acrimonious dispute about the verdict continued with some claiming that justice had been served by passing the verdict since after all if any one person was responsible for how badly prepared Iceland was for the crisis it was Mr. Haarde (Alvarleg ákæra sem erfitt er að refsa fyrir, 2012; Reynisson, 2012). Some commentators emphasized that he fact that Mr. Haarde was neither punished nor even made pay his defense costs, brought out the truth-serving nature of the verdict (Gunnarsson, 2012). Mr. Haarde's supporters on the other hand claimed that the verdict served only to divide Icelanders on how to deal with the crisis and its consequences, not to facilitate reconciliation (Hrakför pjóðkjörinna ákærenda, 2012; Sigurðardóttir, 2012b). The crisis had created deep divisions in Icelandic society-and much distrust in government. Therefore, it was not an infrequent argument that criminal prosecutions of former ministers should be seen as a part of a reconciliation process through which the authorities could regain the trust of the public (Jökulsson, 2010, p. 28; Árnason, 2012; Sigurðardóttir, 2012a).

One of the most common complaints about the verdict was its reliance on the specific and somewhat technical requirement of the constitution described above, to conduct ministerial meetings "on important state matters." Some critics argued that Mr. Haarde had simply been convicted on a technicality and that the absence of the formal meetings required could not be seen as indication that these matters had not been discussed or dealt with as thoroughly as possible at the time (Gissurarson, 2012). Indeed, the extremely sensitive nature of any doubts at the highest level about the performance and viability of the country's financial institutions made it imperative not to bring these matters up formally which could have caused them to become public knowledge, Haarde's supporters argued after the trialeven though the court had dismissed the claim, already made by 
his defense - that such formal meetings would have made matters worse Mr. Haarde argued the same in a letter to the SIC quoted in its report (Special Investigation Commission, 2010b, p. 90). The majority of the court pointed out that it was unclear why consultations at the highest level of government could not be kept confidential (IRR13110314/3.11, 2012, p. 383).

\section{The Necessary Moral Background}

In order to see Mr. Haarde's violation not as a mere technicality, but as criminal neglect, a deeper understanding of this unique verdict is must be gained. I argue that in order to do that it is necessary to go beyond the legal reasoning presented in the verdict and explore the moral grounds of the court's arguments, as presented by the majority. Clearly the claim that Mr. Haarde's fault was simply to fail to conform to a technical requirement undermines the verdict and makes it seem morally questionable even if legally correct. I will argue that there is much more substance in the court's discussion of Mr. Haarde's failure than has generally been acknowledged. An exploration of the court's arguments will serve to bring to the fore the moral reasons for the verdict not fully captured by the legal reasoning. This will lead me to a discussion of the moral justification of the impeachment proceedings as a whole. As I will suggest however, even if the Court of Impeachment was able to convincingly show Mr. Haarde's guilt, it is not necessarily the case that prosecuting him was the best way to deal with such violations, or at the end of the day likely to contribute to national reconciliation-should that have been seen as an important.

\section{WHAT WAS THE CASE REALLY ABOUT?}

The Committee on Legal Affairs and Human Rights of the European Council's Parliamentary Assembly, soon after Mr. Haarde's conviction issued a report by Pieter Omtzigt strongly criticizing the proceedings, arguing that his prosecution amounted to an unhealthy conflation of political and criminal responsibility (Omtzigt, 2013). This report is an important attempt to draw a clear distinction between the political and the criminal. It does so in a way that appeals to common sense: Politicians make decisions based on their best knowledge, but always take the risk of deciding something that later will be seen as a mistake. By criminalizing such failures an intolerable risk emerges for public decision-makers. It is essential for the success of my argument to show why Mr. Omtzigt's analysis fails in Mr. Haarde's case, since it follows that it may be essential that politicians can be seen as criminally negligent in failing to fulfill constitutional or legal duties.

The report addresses the criminalization of political failures and seeks to show that as a rule, politicians should only be prosecuted for criminal offenses (including corruption) - and that "criminal proceedings should not be used to penalize political mistakes or disagreements" (Omtzigt, 2013, p. 3). The report discusses the case of Geir $\mathrm{H}$. Haarde and another recent case, that of former Prime Minister of the Ukraine Yulia Timoshenko, who was convicted for acting against her country's interests in closing an agreement with Russia. It is argued that although these two cases are different, in both cases the main principle of maintaining a separation of criminal and political responsibility is violated (Omtzigt, 2013, p. 21).

Criminal prosecutions of public and elected officials are of course not uncommon. In the United States former officials are regularly prosecuted on a variety of counts, mostly related to corruption (US Department of Justice, n.d.). In European countries legislation offers different paths to prosecution of officials, but abuse of office can be prosecuted in most European countries as well, although the frequency seems to be higher in the US (Zimmermann, 2017b, p. 3, 4). Corruption-whether defined narrowly as the abuse of public office for private gain or more generally, as the abuse of public trust to serve some special interest-is often the focus of possible prosecution, and sometimes the only legitimate reason. In some European countries, government ministers are not prosecuted unless a "property offense" is involved (Zimmermann, 2017a, p. 257). In other countries "violation of duties" can also lead to criminal prosecution and some countries-Iceland among them-focus exclusively on that aspect of ministerial accountability. The case of Geir Haarde is about the violation of duty. His conviction is for neglecting certain duties-i.e., for not taking measures which the court saw as required by the Icelandic constitution. His decision-making is at stake without any allegation of corruption. (See Hauksson, 2010). The prosecution however alleged that dealing with the oversized portfolios of the main Icelandic banks, Mr. Haarde appeared to have "given more consideration to the possible loss suffered by the banks than to the damage to the public interest" (IRR13110314/3.11, 2012, p. 310). But this point is not further developed.

\section{Negligence as Violating Duty}

The central role of such concepts as "duty" and "negligence" in the verdict raises moral questions. When the court sets out to examine to what extent there existed clear duties that in the given situation in Iceland just before the crisis, were neglected, it must do so on the basis of an essentially epistemic assumption about the Prime Minister's awareness of danger. In the verdict a key argument rests on the conclusion that the Prime Minister-because of his educational background (Mr. Haarde has a degree in economics) in addition to his privileged access to information-should or must have understood how serious the situation was (IRR13110314/3.11, 2012, p. 357$358,365,385,397)$. Therefore, at a time when the Icelandic government was actively working with Icelandic bankers and financial leaders to increase international confidence in Icelandic financial institutions, the court concludes that he should have known that these institutions, and with them the state itself, were facing possible financial and economic collapse. It is also made clear that knowledge is precondition for "punishability" (IRR13110314/3.11, 2012, p. 340).

Mr. Haarde's case is controversial precisely because it deals with duty alone rather than with allegations about the Prime Minister's having an agenda opposed to the public interest. That also raises questions about the distinction between violation and failure. Failure can be attributed to bad judgment or lack of understanding. But in this case the court's task was to show not only that the former Prime Minister's actions (or inaction) could 
not be satisfactorily explained as such. If his duty was to act in a certain way in a particular situation, the court needed to establish that he understood the situation to be such yet did not do what he should have done. In the case of corruption, a conflict of interests provides a necessary connection to reality: Public trust is betrayed once the official fails to make sure that his/her actions cannot be seen as serving private interest. The question of duty neglected has no such reality check. Its criminalization therefore is based on logical continuity between knowledge and duty. Given what is known, duty is seen to follow necessarily and vice versa, without knowledge no duty can be inferred. Thus, competence is not at stake even though failure is not assumed to be intentional.

Mr. Haarde's personal qualities-his education, professional experience, and abilities-were referred to by the prosecution to argue that he should be "held to higher standards" than other officials. The court implicitly seems to accept this argument as a part of the reason for concluding that Mr. Haarde knew and understood the danger (IRR13110314/3.11, 2012, p. 296, 297). In its special section on ethics the SIC had made a similar point and even suggested that for this reason the other ministers in the government would have put their trust in his judgement (Rannsóknarnefnd Alpingis, 2010, Vol. 8, p. 151). This clearly raises the question whether in a different situation with a less educated Prime Minister, less would have been assumed about his or her understanding, and consequently a different verdict reached.

In a political system where expertise is rarely what elevates individuals to take on the responsibilities of high office, and a system of public administration is designed to provide immediate in-depth advice to government leaders, the contrary might be assumed, i.e., that the (apparent) lack of awareness should be attributed to systemic failures or to corruption. In Mr. Haarde's case, it was never alleged that his failure to act should be seen as abuse of power. Incompetence and informal practices was certainly one of the issues addressed as partial causes of the flawed response of the government to the coming crisis (Special Investigation Commission, 2010b, p. 147). But it was not seen as a primary cause-only one of the factors that made the government unprepared. Thus, one important premise for the guilty verdict is the assumption that Mr. Haarde was wellequipped to understand the seriousness of the situation even assuming that incompetence plagued the public administration as such. I will argue later in this paper that once this premise is understood, Mr. Omzigt's criticism fails. The premise on the other hand, may, as I will show, be put in doubt.

\section{THE VERDICT: A CLOSE LOOK}

The verdict as a whole is in 13 parts. The first two parts (p. 3-10) describe materials in the case and relevant legislation. The general course of events preceding the Icelandic crisis, highly indebted to the SIC report, is given in the third part (p. 10-134). Part four (p. 134-296) contains summaries of the 40 testimonies given during the proceedings. Part five is a summary of the arguments made by the prosecution (p. 296-317). In part six a summary of the defense is given including the defendant's demand for all counts to be dismissed (p. 317-337). Part seven outlines the law on Ministerial Accountability and its relevant implications for the case (p. 338-343). Part eight covers the reasons for dismissal of the first two counts (p. 343-350). In parts nine through 11 counts $1.3,1.4$, and 1.5 are dealt with and the defendant found not guilty of those counts (p. 350-379). Count 2 is dealt with in part 12 of the verdict and the guilty verdict by the majority of the court then delivered (p. 379-398). Part 13 (p. 398) states that the defendant is not sentenced to punishment. Minority and dissenting opinions are laid out immediately after (p. 399-429) (IRR13110314/3.11, 2012).

At the beginning of its discussion of the implications for the case of the Ministerial Accountability Act, the court established three criteria that must hold in order for a minister's action or inaction to constitute a violation of the law:

1. The welfare of the state must have been in danger.

2. There must have been measures available to avert or reduce the danger which the Minister could have resorted to but failed to do.

3. It must be possible to assume that the available measures would have reduced or eliminated the danger or at least diminished the harm later suffered (IRR13110314/3.11, 2012, p. 339).

Although the court established that all three criteria must hold for a conviction to be justified, it made exception for constitutional requirements. What the constitution explicitly requires of ministers is a duty whether or not particular consequences are to be expected. In Mr. Haarde's case it means that the third criterion is not necessary-guilt can be established by 1 and 2 only (IRR13110314/3.11, 2012, p. 339, 340).

In the verdict the second premise is coupled by the assumption that the prime minister knew or understood the danger (See IRR13110314/3.11, 2012, p. 340, 345). The majority opinion frequently states that he was aware or should have been aware-in the period from February to October 2008- not only that the Icelandic economy was facing major danger, but that in each particular count the circumstances created a specific and avoidable danger, assuming that he had both the information and the ability to understand that this was the case (IRR13110314/3.11, 2012, p. 349, 350).

\section{Counts 1.1 and 1.2}

The first two counts of the first indictment were quite open:

For having shown serious neglect of his duties of office as Prime Minister in the face of major danger threatening Icelandic financial institutions and the State Treasury, a danger of which he was aware or ought to have been aware and to which he would have been able to react by promoting concrete actions, legislation, the issuing of general governmental instructions or the adoption of administrative decisions on the basis of existing law in order to avert foreseeable danger to the welfare of the State.

1.2: For having failed to initiate, either through his own actions or proposals to other ministers, that a comprehensive and professional analysis be carried out within the administrative 
system of financial risks faced by the State due to the danger of financial crisis (IRR13110314/3.11, 2011, p. 1).

The Court of Impeachment dismissed these counts in a decision issued on 3 October 2011. The reason for dismissal was their overly general nature, which made a proper defense difficult (IRR13110314/3.11, 2011, p. 21, 22). The prosecution had argued, however, that the counts should be seen as bringing more substance to the other counts, and the court accepted this point: "The decision stated ... concurring with the defendant that it would not be possible for him to prepare his defense against charges of such general wording as laid on the defendant in that count. It was nevertheless noted that this general description would continue to be seen as part of the indictment, complementary to its other counts" (IRR13110314/3.11, 2012, p. 345). Therefore, even though the specific counts were dismissed, they continued to be a part of the background against which other counts were discussed. This is important for the overall evaluation of the verdict.

It is easy to see why counts of this sort are seen as too general: They simply state the conditions of a guilty verdict laid out by the court in the verdict itself. The court does not see it as its task to determine in general whether duties were neglected, or initiatives not taken, the task is, rather, to determine whether acts not done and initiatives not taken can be shown in concrete cases to constitute neglect to the point of being a violation of law (IRR13110314/3.11, 2012, p. 344). Other argumentation on later stages in the verdict depends on this understanding when the question of a constitutional duty to hold ministerial meetings is discussed. The mere technicality of holding or not holding meetings is not a stake, but rather the particular neglect constituted by not holding these meetings under the particular circumstances described.

\section{Counts 1.3, 1.4, and 1.5}

So, the first count that the court actually upheld was 1.3 which concerns the work of a consultative group on financial stability and defenses, appointed by the government to monitor the situation and advise the government. The apparent lack of seriousness and evasive reactions to signs of danger had appalled the SIC as is duly noted in its report (Special Investigation Commission, 2010a, p. 11). In the indictment Mr. Haarde is accused of carrying the responsibility for this lack of success:

1.3 For having neglected to ensure that the work and emphasis of a consultative group of the Government of financial stability and preparedness, which was established in 2006, were purposeful and produced the desired results (IRR13110314/3.11, 2011, p. 1).

The group was composed of officials from several ministries, the National Bank and the Financial Monitoring Authority. Its role was to advise the government on issues related to the banks. The group was put together in 2006 when doubts about the viability of the Icelandic banks surfaced. One of its members was the permanent secretary in the Prime Minister's office with whom Mr. Haarde had close working relations (IRR13110314/3.11, 2011 , p. 11). The group met several times over the period from
February to October 2008, but little concrete advice came from it. It seemed at least clear that the expertise of its members was not fully used and the group's capacity for preparing the ground for serious policymaking was not exploited to any significant degree (Rannsóknarnefnd Alpingis, 2010, Vol. 6, p. 245). The court however found that the Prime Minister was not to blame that the work of the group was not as focused and productive as could have been desired. Also, the court could not see that increased efficiency in the work of the group would have made a significant difference. The government certainly failed to form policy based on the group's analysis, but many other resources were also available. Therefore, even given that the Prime Minister had made more efficient use of the group's work the precise beneficial effects of that could not be clearly spelled out (IRR13110314/3.11, 2012, p. 358, 359).

This conclusion has a technical character. The count is specific, claiming that the Prime Minister was in a position to direct the work of the consultative group to a greater extent and consequently gain better instruments to deal with the imminent danger. He did not do so. While the court clearly acknowledges flaws in the way the group worked as well as in how the government used it or failed to use it, the count fails on both criterion 2 and 3: It is not clear what the Prime Minister should precisely have done about the group, and it is not clear either that acting on the group's recommendations (whatever they were or would have been) would have reduced the danger (IRR13110314/3.11, 2012, p. 358).

The second active count-1.4-points specifically to the government's leverage over the banks. The SIC had criticized the government harshly for not using its power-while there was still time to do so-to make the banks less dangerous by making them reduce their portfolios or move parts of their operations abroad, out of Icelandic jurisdiction (Rannsóknarnefnd Alpingis, 2010, Vol. 6, p. 264). So, the count is:

1.4 For having neglected to take initiative on active measures on behalf of the State to reduce the size of the Icelandic banking system by, for example, advocating that the banks reduce their balance sheets or that some of them move their headquarters out of Iceland (IRR13110314/3.11, 2011, p. 1, 2).

Here the claim is that the Prime Minister could have taken measures to force the banks to make their portfolios smaller or move abroad, that he had these two options but failed to act on either of them. The court agrees to this claim-i.e., agrees that it was in his power to initiate this by forming a corresponding government policy, and with the Minister of Banking and Trade direct the National Bank and the Financial Supervising Authority to force the banks to act accordingly (IRR13110314/3.11, 2012, p. $368,370)$. The court, on the other hand, concludes that there is no guarantee that the results of such a policy would have been to reduce danger. Some scenarios even suggest that forcing the banks to reduce their portfolios could at some point have been counterproductive. So, criteria 1 and 2 are fulfilled, but not 3 (IRR13110314/3.11, 2012, p. 371, 372).

The court points out that some of the measures available to the government would have required major loan guarantees and 
other temporary measures, imposing considerable risks on the state for certain periods of time (IRR13110314/3.11, 2012, p. 361365). Such measures could have backfired. Therefore, even given full knowledge of the danger, Mr. Haarde cannot be expected to have known which of a number of options was safe or even better than not acting at all.

This issue is addressed in an even more specific way in subcount 1.5-the third active count, where Mr. Haarde is made partly responsible for the so-called IceSave debacle, i.e., the demand that the Icelandic government faced after the collapse of Landsbankinn to pay the total deposit insurance of private account holders in the UK and Holland, whose deposits had evaporated with the collapse of Landsbankinn. The count is as follows:

1.5 For not having followed up and assured himself that active measures were being taken in order to transfer Landsbanki íslands hf.'s Icesave accounts in Britain to a subsidiary, and then to look for ways to enable this to happen with the active involvement of the State (IRR13110314/3.11, 2011, p. 2).

Since the greatest damage that the crisis to begin with seemed to have caused to the Icelandic state was the enormous debt to Holland and the UK due to the failed IceSave accounts, one of the big questions after the collapse of Landsbankinn was why the government had not made sure that such a liability did not exist. This was thoroughly discussed in the media and in various reports, including the SIC report (Rannsóknarnefnd Alpingis, 2010, Vol. 6, p. 7-65). The court on the other hand concluded that a transfer of these accounts to a UK subsidiary, which would have meant that deposits were not insured through the Icelandic bank insurance fund, was hindered partly by requirements in the UK and that even if this was desirable it could not be seen as the responsibility of the Icelandic government to demand or negotiate this. Moreover, the court concluded that Mr. Haarde could be seen as having believed that the directors and owners of Landsbankinn were actively seeking ways with the British government to move the accounts to a UK based subsidiary (IRR13110314/3.11, 2012, p. 377, 378). But this was not the case and, as the court points out, in fact was not directly in the interest of Landsbankinn. Mr. Haarde's gullibility about this however seems not to disturb the majority or lead to the conclusion that Mr. Haarde should have known that Landsbankinn was unlikely to seek any solution of that sort without continuous pressure from the government. The court therefore saw criterion 1 to be fulfilled but neither 2 nor 3 (IRR13110314/3.11, 2012, p. 379).

\section{Count 2}

This sixth part of the indictment is much more specific than any of the counts in in the first part of the indictment. Here the reference is very literally to the demand explicitly laid out in the constitution, that the ministers in the government meet to discuss policy-i.e., that the government formally discuss and deal with important state matters. Article 17 of the Icelandic constitution is unequivocal about this requirement. It says: "Ministerial meetings shall be held in order to discuss new legislative proposals and important state matters." (Constitution of the Republic of Iceland, 1944, art. 17). So, count 2 looks as follows:

2 For having, during the above-mentioned period [February 2008 - October 2008] failed to implement what is directed in Article 17 of the Constitution of the Republic on the duty to hold ministerial meetings on important government matters. During this period there was little discussion at ministerial meetings of the imminent danger; there was no formal discussion of it at ministerial meetings, and nothing was recorded about these matters at the meetings. There was nevertheless specific reason to do so, especially after the meeting on 7 February 2008 between him, Ingibjörg Sólrún Gísladóttir, Ãrni M. Mathiesen and the Chairman of the Board of Governors of the Central Bank of Iceland; after his and Ingibjörg Sólrún Gísladóttir's meeting on 1 April 2008 with the Board of Governors of the Central Bank of Iceland; and following a declaration to the Swedish, Danish and Norwegian Central Banks, which was signed on 15 May 2008. The Prime Minister did not initiate a formal ministerial meeting on the situation nor did he provide the Government with a separate report on the problem of the banks or its possible effect on the Icelandic State (IRR13110314/3.11, 2011, p. 2).

Here the majority of the court accepts the claims made by the prosecution, i.e., it considers all three criteria to be fulfilled: There was known and present danger, the Prime Minister could have reacted in the proper manner but did not and doing so would in have led to at least better preparations to be in place when the crisis hit (IRR13110314/3.11, 2012, p. 396).

When the court's final conclusion on this count is read, the purely technical nature of the violation seems at first striking, not least when it is kept in mind that the court has also determined that in the case of a constitutional violation, the defendant could be found guilty even without criterion 3 being fulfilled, i.e., even if it were seen as unlikely that ministerial meetings would have changed anything at all. Even so it is quite clear that the assumption that such meetings-and the work that would have resulted from a formal approach to the difficulties-would have changed the situation is an important part of the majority's conclusion (IRR13110314/3.11, 2012, p. 396, 397).

But the verdict also brings us back to counts 1.1 and 1.2 and the court's ominous statement about the relevance of those counts to the case in general. This seems to imply that the court considers each of the counts to contain the more general complaints implied by the dismissed counts, even though the defendant cannot be convicted on the basis of them alone. Conviction on any of the counts should then be understood as the conclusion that by failing in the specific actions described in each count, the Prime Minister failed to initiate important and necessary measures and failed to ensure the proper analysis of the situation. Thus while the Prime Minister, and by extension the government, was or should be aware that Icelandic society was facing imminent danger he neither studied the situation to sufficiently in its scope and depth nor did he initiate measures that could have reduced the danger, according to the majority's conclusion (IRR13110314/3.11, 2012, p. 395, 397).

Although it may well be argued that per se the conviction on count 2 could have been based on a technical reading of 
TABLE 1 | Conditions of conviction.

\begin{tabular}{llll}
\hline $\begin{array}{l}\text { Conditions } \\
\text { of } \\
\text { conviction }\end{array}$ & $\begin{array}{l}\text { Danger } \\
\text { present for } \\
\text { society }\end{array}$ & $\begin{array}{l}\text { Measures } \\
\text { available to } \\
\text { defendant }\end{array}$ & $\begin{array}{l}\text { Danger } \\
\text { reduced by } \\
\text { taking } \\
\text { measures }\end{array}$ \\
\hline 1.3 & Fulfilled & Not fulfilled & Not fulfilled \\
1.4 & Fulfilled & Fulfilled & Not fulfilled \\
1.5 & Fulfilled & Not fulfilled & Not fulfilled \\
2 & Fulfilled & Fulfilled & Fulfilled \\
\hline
\end{tabular}

the constitution, the rest of the court's arguments shows that it is not. The emphasis the majority puts on showing that it indeed fulfills all three criteria suggests some uneasiness about basing the verdict entirely on such legal-technical reasoning. By going beyond it the majority in fact issues the most pointed and comprehensive moral condemnation of the Icelandic government to come out of reactions to the 2008 crisis.

It is important here to recall that one of the main arguments made by the defense during the trial, to justify not only inaction of the Prime Minister, but indeed of the whole government in the months preceding the crisis, had to do with the sensitivity of the situation: If the government would show in any way that its confidence in the banks or in the Icelandic banking system was faltering, this would have had immediate and devastating consequences for the Icelandic banks. In a difficult situation-so it was argued-it could even cause their failure. The court admits that the situation was unusually sensitive which made it all the more complicated, but it categorically dismisses the conclusion that such sensitivity made it impossible for the government to fully discuss the issues in ministerial meetings and follow up on such discussion with the planning, policy-making, research, and analysis necessary (IRR13110314/3.11, 2012, p. 396). The claim, made in depositions, by some of the earlier members of the government's consultative group that the government was both quick and efficient in its reactions once the crisis had hit, is accepted by the court, but that makes the question all the more pressing why the government could not react as efficiently earlier, even though strictest confidence would have been required.

Failure to hold ministerial meetings thus implies the more general notion that the government, under the leadership of the Prime Minister was almost paralyzed. Consultations and meetings with officials, memoranda from specialists and information coming in from various different sources shows that key actors in the government and the governmental administration understood the general nature of the danger and also had some conception of the consequences of systemic bank failure. Yet none of their activity was as focused and solution oriented as citizens could rightfully expect from their democratic government. Instead ministers seemed entirely at the mercy of the big banks and simply repeated their claims that the "longterm prospects" of the banks were good, i.e., the given they would overcome temporary liquidity problems they would be able to manage their portfolios and continue to thrive (Mishkin and Herbertsson, 2006; Portes and Baldursson, 2007, p. 36).
The majority does not specify what kind of measures the government could have initiated but instead argues that if a more systematic response had been orchestrated, using all the available resources of the state, including the cooperation with other countries, the reality would probably have been different from what turned out at the beginning of October in 2008. The majority concludes that holding the required ministerial meetings would have forced the government to face the problems at a more formal level and made it stronger.

The court may here be seen as upholding a double strategy. On the one hand there is a violation-criminal negligence-once a duty to act is established, and therefore the Prime Minister could be convicted on those grounds alone. But whatever the court would have done in the absence of a reason to conclude that to act would have made any difference in the particular situation Iceland was in during the months before the crisis, the majority finds it important to embed the conviction in in a conclusion where that is assumed.

Count 2 had also led the defense to engage in scholarly debate on the interpretation of article 17 of the constitution which sets out the requirement for ministerial meetings. The defense argued that this requirement should be understood very narrowly and indeed as a remnant of a previous constitution, valid before the founding of the Icelandic republic, when the head of the Icelandic state was the Danish king. In the older constitution the requirement to hold ministerial meetings is closely connected to another article of the constitution, requiring important government matters to be presented to the king by the prime minister. Given this historical context, article 17 should simply be seen a stipulating that important matters of state, before being presented to the president in the so-called state council, should first be discussed by the ministers in the government (IRR13110314/3.11, 2012, p. $336,337)$.

The court dismissed this argument saying that this did not make sense as a part of the constitution of the republic since now the State council included all ministers, while during the Icelandic kingdom the King was met by the prime minister alone who then presented important matters to the King. The majority thus chose to see the article not as an accidental remnant of earlier times but as an important part of the constitutional order, making it clear that the government was under an obligation to work together to mobilize all available resources to deal with important state matters especially in the time of "major danger" looming over Iceland (IRR13110314/3.11, 2012, p. 380-383).

An overview of the court's conclusion in 1.3, 1.4, and 1.5 and the majority's in 2 is shown in Table 1 . The moral dimension of the majority's argument emerges from the court's detailed discussion of the government's failure to reduce the danger it faced, which draws on various arguments and conclusions made in the discussion both of the counts of which Mr. Haarde was acquitted and the counts dismissed. Since the argument is not strictly speaking necessary for justifying the conclusion, its achievement is to cast light on a more general aspect of the government's action/inaction between February and October 2008 , condemning the failure to form a policy in time to deal with situation the country was facing. 


\section{THE ETHICS OF MINISTERIAL ACCOUNTABILITY}

The Icelandic law on ministerial accountability has its origins in earlier legislation from before Icelandic independence. So do the constitutional articles on the court of impeachment and Althingi's right to initiate impeachment proceedings. The current law is from 1963, the constitution from 1944. In the explanatory notes on the bill from 1962 in which a new law on ministerial accountability was proposed, the need for such a law is explained by the special nature of violations that a minister may commit while in office: "The ministers find themselves in a situation so special that they may commit violations in their role that is hardly thinkable for other public officials ${ }^{3}$. The special legislation also emphasizes ministerial accountability, so expressed in the constitution: "Ministers are accountable for all executive acts" (Constitution of the Republic of Iceland, 1944, art. 14). The special status of ministers among public officials was further established with a special ethical code for ministers which slightly differs from a parallel code for government employees (Code of conduct for government ministers, 2011).

With the 1963 law it is firmly established that political accountability is considered insufficient means to monitor and control ministerial conduct (Act on Ministerial Accountability, 1963). While the parliament may impeach a minister guilty of abuse of power or of corruption, or of negligence of duties, a lack of trust may have different grounds reflecting political conflict and various other reasons. But the specificity of a law on ministerial accountability also has consequences for the dominating conception of ministerial accountability in general, and thereby for the ethical and moral demands that result from such a conception.

\section{The Role of Ministers in the Icelandic Constitutional Order}

According to tradition-as well as law-ministers are very independent in the Icelandic governmental system. They alone are accountable for executive acts, individually, each minister. Consequently, the Prime Minister is not accountable to a greater degree than any other minister. He or she answers for his or her own portfolio, which of course includes organizing, coordinating and leading the general policy-making tasks of the government.

In the report previously discussed, entitled "Keeping political and criminal responsibility separate" Pieter Omtzigt-member of the Parliamentary Assembly of the Council of Europeargues that it is an important goal of any democracy to avoid criminalizing political decision-making. Omtzigt argues that it was a new parliamentary majority which made the decision to initiate the impeachment/indictment procedures, that the vote was determined mainly by party affiliation and further that it "would indeed appear that the new majority's objective was to somehow "criminalize" their predecessors' choice of economic liberalism that had contributed to the rise and fall of the Icelandic

\footnotetext{
${ }^{3}$ Icelandic: "En staða ráðherra er svo sérstæð, að peir geta orðið sekir um pað misferli í starfi, sem vart eða ekki er hugsanlegt hjá öðrum opinberum starfsmönnum.” Frumvarp til laga um ráðherraábyrgð (1962), p. 4.
}

banks" (Omtzigt, 2013, p. 6). Omtzigt maintains that "the overzealousness of the special prosecutor pinning him [the former Prime Minister] down for a formal violation which, in addition, corresponded to a long-standing practice dating back to before the independence of Iceland, and several other issues... make this case a violation ... of the "guiding principles" of keeping political and criminal responsibility separate...” (Omtzigt, 2013, p. 21).

Omtzigt's argument is directly opposed to the worries expressed in the explanatory note to the Ministerial Accountability Act, where the legislation dealing specifically with actions of ministers is seen as a measure to prevent the politicization of criminal wrongdoing specifically tied to the office of ministers because of the role played by ministers in state administration.

\section{Why Criminal Accountability Is Central}

There are factual errors in Omtzigt's report that make it difficult to fully assess his argument, but more importantly the idea of an overzealous prosecutor acting on politically motivated instructions may not be an entirely fair description of the affair. Instead my reading of the case suggests that the existence of the Ministerial Accountability Act as well as the constitutional article on ministerial meetings provided an important way for the political system to go through a thorough examination of ministerial conduct and to make an attempt to distinguish between culpable action/inaction on the one hand and conduct that should not be so evaluated on the other, even when measures taken and decisions made would in hindsight be judged to be wrong.

Even though the Court of Impeachment could only provide a determination of legal violations the proceedings as a whole were an opportunity for a moral evaluation of governmental action badly needed after the crisis, but only partly met in the report produced by the Special Investigation Commission which included one volume on ethics. This part of the report was written by a subcommission which focused entirely on the moral and ethical sides of the conflict and did not attempt to draw conclusions about legal ramifications. The report focuses heavily on political and administrative culture, informal ways of making policy and lack of professionalism. The problem of Icelandic governance is described as "broad, deep, and systemic" in the report's closing statements (Rannsóknarnefnd Alpingis, 2010, Vol. 8, p. 243). Thus, while it is certainly important in a democracy respecting the rule of law, not to abuse the political process by making policy decisions subject to criminal investigations, it is at least equally important to be able to scrutinize political action and inaction from a more demanding point of view, relying on judicial as well as ethical principles-not only on political rhetoric or ad hoc justifications. In an important sense therefore, it can be said that the possibility to treat some of Mr. Haarde's negligence and failures as criminal offenses was an important opportunity to deal with the crisis and move beyond it.

The court's majority opinion provides a discussion of government inaction-perhaps inability or incompetence-to deal with what governments under all circumstances must do: React to events and developments in the world that affect their public and seek initiatives to reach goals that they 
have committed themselves to and even promised to reach. Mr. Haarde had from the beginning of the crisis in Iceland categorically rejected the accusation that his government or he himself were in any way to blame for how things ended. The Icelandic crisis was entirely a result of the international financial crisis according to him and what the government could do it had done. He made this point very clearly in an address to the Icelandic nation broadcast directly on television after the government had taken over the biggest banks in Iceland, on 6 October 2008, and the public was beginning to understand the magnitude of the crisis. Mr. Haarde never wavered from this understanding of the crisis in his public comments (Haarde, 2008).

The verdict presents a strong denial of Mr. Haarde's view arguing indirectly that a competent government would have needed to wriggle out of the grip it was held in by the powerful banks who effectively held the government hostage to their interests. But the government never tried to distance itself from the banks and withheld any criticism of them. Instead government ministers kept whispering in corridors, consulting privately even making sure that only a group of a few initiated was really in the know, yet unable to act boldly or independentlycaptives of the circular reasoning imposed on them by the financial leaders according to which the banks were in good shape and their prospects good and therefore they not only needed to be saved, but also deserved to be helped in a moment of need (Rannsóknarnefnd Alpingis, 2010, Vol. 8, p. 155).

\section{Whether the Reasons for Indictment Were Political}

This general background of the indictment (the government's reaction and planning indeed were incompetent) calls for explanation, and that is where the legislation on ministerial accountability brings substance to the discussion. Pieter Omtzigt's claim that the indictment was essentially political since it dealt with policy decisions made (or not made) by the Prime Minister, if correct, amounts indeed to a very serious criticism. But the law, as well as the constitution, is designed to deal with cases were the question is precisely what duties where at stake and whether these duties were violated-not only whether ministers are abusing their office for personal profit or to serve special interest. The legal background thus necessitates the question what duties were involved in a situation where the government to a significant degree failed. Mr. Omtzigt's reasoning is therefore flawed: He seems to think that the prosecution is motivated by a desire by Mr. Haarde's political opponents to show that his policies were wrong, whereas it is not a question that the government's reaction to the signs of crisis was a failure. The question was whether this failure should be seen as a violation of legal duty. In an environment where accountability depends on duty legally characterized, one might argue that failing to prosecute a violation of duty should evoke suspicion of political motivation rather than vice versa.

The concept of legal duty itself, however, raises interesting theoretical questions, not addressed in the verdict. Since the very idea of ministerial accountability points to the consequences of public action or decision-making, it may seem disingenuous that a minister might be convicted for acting (or not acting) in a way that conflicts with legal duty without any regard to the consequences of that action or inaction. Indeed, it might be seen as legalism-an obstacle to sensible government (See Mulgan, 2003, p. 83). Yet the court makes clear that the constitutional requirement to hold ministerial meetings must be kept "irrespective of consequences (IRR13110314/3.11, 2012, p. 339)." As I have pointed out already, since the majority opinion assumes implicitly the truth of the charges that were either dismissed or of which Mr. Haarde was found to be not guilty, it cannot be shown to have convicted Mr. Haarde of a mere technicality as a few critics claimed, some of them framing the argument somewhat ludicrously (see e.g., Gissurarson, 2012). But that does not answer the question whether convicting a former minister for a mere violation of legal duty is justifiable from a moral standpoint. Since it seems to follow from the verdict, that a judicial treatment in such a case might simply disregard a possible explanation and justification of the violation, one should conclude that this position cannot so easily be morally supported. Ministerial accountability is primarily (and minimally) about the demand that public officials who are given power to make decisions, do so in a transparent manner and can be able to justify their course of action when necessary (Bovens et al., 2014, p. 6). Absolutism about legal duty may not serve that purpose.

\section{The Knowledge and Understanding Condition}

I want to return now to the epistemic assumption I briefly discussed earlier in this paper. As the verdict clearly shows, in particular the final argument leading to the majority's conclusion that Mr. Haarde is guilty of having as Prime Minister violated a constitutional duty, much depends on his knowledge and understanding of economical matters. The assumption that his personal experience and knowledge was such that he must have understood the danger ahead is prima facie problematic since it takes two things for granted:

1. The seriousness of the situation must have been fully understood by him.

2. The vulnerability of the banks he must have grasped.

3. He must have been wrong about not trusting some of his ministers.

The majority opinion suggests knowledge in 1 and 2 was considered sufficient condition of culpability. But the question must also be asked whether Mr. Haarde sincerely believed that holding formal ministerial meetings about the danger presented a risk, since having that belief would make it plausible to say that he was in fact not negligent but simply mistaken. The discussion about such fears and Mr. Haarde's view that formal discussion could have made things worse is seen as somewhat paradoxical in the Special Investigative Commission's report: Suggesting on the one hand an understanding of the danger, on the other a state of denial (Rannsóknarnefnd Alpingis, 2010, Vol. 8, p. 148). Neither the defense nor the court's minority however argued that the Prime Minister was simply mistaken 
in his view. The defense engaged in an arcane legal argument to show that the constitutional article did not really impose the duty on the Prime Minister to convene ministerial meetings on all "important state matters." Neither did the former Prime Minister's defense nor the court itself ever try to establish that the Prime Minister might have acted as he did because of major deception. Yet Iceland at this time still enjoyed a reputation of having excelled in international banking and become a cradle of the financial elite of the future. In 2006 and 2007 many public leaders in Iceland made bold claims about Iceland's banking success - the president of the country perhaps the boldest, as can be seen from his speeches at the time (see e.g., Ólafur Ragnar Grímsson, 2006). The emphasis on the image of the banks as they were on the verge of ruin is often described as "absurd" in later economic analysis (see Hilmarsson, 2013, p. 44). The opinion expressed time and again, by analysts and financial leaders alike, that the banks' problems were temporary, that their long-term prospects were good. Although it is certainly true that many things indicated that they were facing not only liquidity problem, but also deeper equity problems, there was still a lot of expert opinion around that downplayed their problems (IRR13110314/3.11, 2012, p. 365). As some of those who gave testimony at the trial, e.g., Ingibjörg Sólrún Gísladóttir the former Minister of Foreign Affairs, also pointed out, such expert opinion seemed to justify the belief that problems were indeed temporary (IRR13110314/3.11, 2012, p. 365).

We may assume that individuals are responsible for their beliefs in so far as they have control over them. Although control over beliefs is indirect-it depends on the management of e.g., evidence, and being open (undogmatic) to evidence. Mr. Haarde's inclination to believe those who downplayed the danger however is not incomprehensible. He can still be seen as a smart, educated and experienced person genuinely seeking solutions. Therefore, it may be somewhat unfair to grant that given his understanding and privileged access to information and obvious criticism of his actions (or inaction), his failure to act accordingly must be seen as culpable, i.e., as "gross negligence (See e.g., Cassam, 2019, p. 121-125)."

The majority makes it clear that Mr. Haarde's knowledge is a necessary condition for his conviction and assumes given the information he had that he must or should have known that the conditions were such that they required the prescribed ministerial meetings. It does not review or consider the possibility that because of the previously established over-confidence in the banks the Prime Minister may-as most Icelanders at the time-may have been unable to fully realize how bad the situation was. Surely the Prime Minister should have reevaluated his belief in the banks given the circumstances and one may argue that he is responsible for adjusting his beliefs given the available evidence. But as the majority also points out "various information also indicated that the banks' position was not bad in fact" (IRR13110314/3.11, 2012, p. 365). Confirmation bias and selectivity in evaluating evidence is clearly an epistemic vice-but not necessarily culpable-let alone a criminal offense (Fricker, 2007, p. 100; Cassam, 2019, p. 137, 138).

In the absence of a clear institutional response the personal qualities of individual leaders gain importance, and this should be taken to support legal accountability. The responsibility carried by leading figures may be compared to the responsibility of highrisk professionals whose mistakes have devastating consequences and therefore are in some cases liable to be prosecuted. Making negligence criminal emphasizes the central place of the government in the lives of the citizens. To do so may carry the risk of abuse, but on the other hand it may also serve to move "matters of state" outside of a narrow, yet shifting, ideological context. Whatever the dominating political orientation of the government and possibly dogmatism, it cannot neglect the formal, direct, and serious duty to react to and deal with dangers such as the one looming in 2008.

Apparently, the Prime Minister-and other ministersbelieved themselves to be locked in a situation where the best they could do was to continue a PR campaign where doubt about the international banks was countered by stronger and stronger claims about their strength and viability. When the court however refuses to acquiesce in the commonly held view that this collective illusion must simply be accepted, it makes the abilities and personal qualities of the Prime Minister morally significant. The situation was such that it required to be formally discussed in ministerial meetings and the Prime Minister must have known/should have known that this was the case. Moral significance translates into legal accountability and completes the basis for conviction. But that does not necessarily imply fairness (Hjalmarsson and Kovras, 2017).

\section{WAS IT WORTH IT? WAS IT FAIR? - WAS IT DEMOCRATIC?}

When Althingi voted on four resolutions on 28 September 2010, on whether to initiate legal proceedings against four former ministers in the government, it did so in an atmosphere of distrust and mutual contempt. Most of the parliamentarians -55 out of 63-wanted either to prosecute all of the four or no one (25 wanted to prosecute them all, 30 wanted no prosecutions). Some parties were split and no consultation about strategy was made before the vote. Some of the MP's had not made up their minds about how to vote until the last moment ${ }^{4}$.

The four ministers were in addition to Geir Haarde, Ingibjörg Sólrún Gísladóttir, former foreign minister (fMFA) and head of the Socialdemocratic Samfylkingin, Árni Mathiesen, former finance minister (fMF) who belonged to the Independence party and finally Björgvin Sigurð ${ }^{\star}$ sson, former minister of banking and trade (fMBT), an MP for Samfylkingin. At the time only Björgvin Sigurð* ${ }^{*}$ sson was still serving as MP, but he took a leave of absence while Althingi dealt with impeachment proposals (Alpingismannatal, n.d.).

The results of the vote are listed in Table 2:

All MP's for the Conservative Independence party opposed indicting any of the former ministers. Some Progressive party MP's (formerly a coalition partner with the Independence party), voted against, while some voted to indict all four. The MPs of the Socialist left-green movement-in power with the Social

${ }^{4}$ This assessment is based on confidential conversations with some of the MPs who took part in the vote. 
TABLE 2 | Vote on indictment, results.

\begin{tabular}{|c|c|c|c|}
\hline & $\begin{array}{c}\text { Favoring } \\
\text { indictment }\end{array}$ & $\begin{array}{c}\text { Against } \\
\text { indictment }\end{array}$ & Abstentions \\
\hline Geir Haarde (fPM) & 33 & 30 & 0 \\
\hline $\begin{array}{l}\text { Ingibjörg Sólrún } \\
\text { Gísladóttir (fMFA) }\end{array}$ & 29 & 34 & 0 \\
\hline Árni M. Mathiesen (fMF) & 31 & 32 & 0 \\
\hline $\begin{array}{l}\text { Björgvin G. Sigurðsson } \\
\text { (fMBT) }\end{array}$ & 27 & 35 & 1 \\
\hline
\end{tabular}

TABLE 3 | How MPs voted.

MP's against indicting anyone

MP's in favor of indicting former PM, MF, MFA, and MBT

MP's in favor of indicting only former PM, MF, and MFA

MP's in favor of indicting only former PM, MF, and MBT

MP's in favor of indicting only former PM

25

4

2

2

democrats at the time voted in favor of indicting all four, and the Movement-MPs who had been elected on the platform of Citizens' movement, formed during the 2008 crisis and the smallest group of MPs in parliament-was also united in favor of indicting all four. A dramatic and decisive split occurred within Samfylkingin - the social democratic party, whose leader Jóhanna Sigurðardóttir led the post crisis government, but had also served in the pre-crisis government along with the two former ministers from her party whose indictment the Parliament now voted on. Eight of its MP's voted not to indict all four, but only some (See Atkvæðagreiðslur priðjudaginn, 2010).

Table 3 shows how the vote thus was split in five different ways:

One way to break these results down is simply by indictment/no indictment. Thirty-three MP's were in favor of indicting someone-i.e., a majority in comparison with a minority against indicting anyone. But the MP's who want someone indicted are split in a way that the former minister of finance narrowly avoids prosecution, whereas the Prime Minister-appearing in all combinations, does not. The reluctance of some of the Social democratic MP's to either go against everyone or no one apparently had different reasons. In the report of the Special Investigation Commission no suggestion had been made about prosecuting the former MFA since her direct responsibility as minister was not the financial system (Special Investigation Commission, 2010a, p. 18). The parliamentary committee which presented proposals to the parliament based on the report on the other hand included her as de facto deputy leader of the government (Skýrsla pingmannanefndar til að fjalla um skýrslu rannsóknarnefndar Alpingis, 2010). So, three MP's appear to be following the Special Investigation Commission's report, while two oppose the idea of prosecuting the former Ministers of banking and Tradewho was also seen as a victim of the crisis, being the member of cabinet consistently excluded even from information directly
TABLE 4 | How parties voted.

All No one fPM, fMF, fMFA fPM, fMF, fMBT fPM

\begin{tabular}{lccccc}
\hline Independence party & & 16 & & & \\
Progressive party & 6 & 3 & 4 & 2 & 2 \\
The movement & 3 & & & & \\
Social democrats & 1 & 11 & & & \\
Left green movement & 15 & & & & \\
\hline
\end{tabular}

relevant to his office. And then there were the two outliers, two social democratic MP's who argued that the one who really should be seen as accountable for the government's failure to react adequately and in a timely manner was Geir Haarde, the former Prime minister. They consequently voted to initiate legal proceedings against him alone, and they won the day.

The result shows prima facie that what the majority wanted was to indict Geir Haarde, whereas there was no majority for indicting the others. The vote was not entirely along party lines, since two parties were split. Table 4 shows the relationship between how the vote fell and party affiliation:

But to interpret the results in such a way is to ignore the preference ranking that came so clearly to the fore in public discussion after the vote. Opinion polls, before the parliament made its fateful decision, suggested that a great majority of Icelanders supported the idea of legal prosecution of government ministers for their failures before the 2008 crisis. But even if public opinion supported prosecutions, doubts were often voiced in public discussion, that the political elite would stick together, rather than break ranks and elite cohesion would prove stronger than the willingness to prosecute former ministers for negligence.

Once the Parliament had made its decision, however, a different view emerged. The fact that only the prime minister was to be prosecuted angered a sizable part of the population according to opinion polls. Many people now felt that the prime minister was the victim of politically motivated harassment; that his political opponents were using the opportunity to get revenge on him and his party.

What this public reaction may serve to emphasize is the unsure relationship between public opinion and judicial argument. While the court attempts in its verdict to establish personal guilt with a clear and detailed argument, the public tends to take a broader view. It was seen as deeply unfair (by many) to pin the blame on the Prime Minister alone. The verdict shows how he can nevertheless be made accountable beyond the accountability of individual ministers. But even if guilt can be established, it does not mean conviction must be sought. If the idea with the prosecution was to resolve or get to the bottom of governmental accountability before and during the crisis-in order to serve transparency and prepare for future challenges, it certainly did not reach its purpose, unsurprisingly, perhaps (See Hilliard et al., 2021).

In a liberal society-a constitutional democracy-guilt is individual rather than collective. Therefore, the Parliament could only vote separately on each indictment. But from a moral point of view evaluation of the act must also be collective-it is the evaluation of a deed made by many people together, who bear 
responsibility together, not only individually. Therefore, it is also not unlikely that some of the MPs who voted to indict all four Ministers would have preferred the option of indicting no one to the option of indicting only the Prime Minister. But since MPs were unable (or unwilling) to form alliances a democratic paradox may have occurred: The result was obviously far from reflecting the first preference of the MPs-it was the first preference of only two MPs. The question is whether it reflected the second preference or even the third preference of the majority. While this question cannot be conclusively answered here, at least it can be argued that this might well not be the case. The individualized vote and mutual distrust before the vote made it difficult to avoid this result, given that there were two MPs who felt that the Prime Minister should alone face criminal charges.

Some MPs have reported that they felt great unease after the decision was made. While they would have seen it as a disaster to fail to prosecute any of the former ministers, they also felt that putting all the blame on the former Prime Minister was very difficult outcome. This suggests that misgivings within parliament about the results were probably similar to the doubts felt in society at large.

\section{CONCLUSION}

A final assessment of Althingi's decision to prosecute a former Prime Minister-a politician who was not suspected of corruption or of willingly having served other interests than the state's and the nation's is and will be mixed. On the one hand, as I have argued in this paper, the proceedings brought to the fore the fundamental failure of the Icelandic government to react in a systematic, professional and responsible manner to signs of the coming crisis early in 2008. This is in my view an exceptionally important achievement, but largely ignored because of the judicial nature of the proceedings. On the other hand, the affair singled out an individual who had found himself in a situation without precedent, surrounded by bewildered officials and a powerful financial elite that had in the years before the crisis enjoyed almost universal admiration for its perceived successes. The court assumed that Mr. Haarde's position, previous experience and knowledge made it impossible for him not to understand the seriousness and threat of developments in international finance in 2008.

The government was paralyzed-until it was forced to act, but then it did so swiftly. During the trial some of the people who appeared before the court pointed this out to support the belief that all resources were mobilized as soon as the magnitude of the crisis was understood. One of the important post-crisis issues however must be to explore the paralysis, why it lasted so long and what caused it. But once former officials and political leaders face possible criminal charges their inclination to facilitate such understanding may diminish. Prosecution inevitably puts everyone involved on the defensive. Instead of willingness to concede and participate in an attempt to come to terms with what had happened, former ministers and officials early on understood that for them a more sensible way was to prepare their defenses. The choice to prosecute can in this sense be compared to choices faced by governments dealing with social recovery after periods of civil wars or violence (Patel et al., 2009). It will be difficult for victims to accept that perpetrators of violence are given a way out and even trusted to tell the truth, yet the value of testimony may well be greater than the value of punishing the guilty.

I have argued in this paper that the criminal case against Geir Haarde produced a guilty verdict (even if not a unanimous one) against a background of a moral evaluation where accountability is partly determined epistemically: Assumptions are made about what the Prime Minister must have known, and normative conclusions are then drawn from such assumptions. While the verdict helps put the question of failure in a sharper light and certainly justifies legal intervention as such its usefulness has been limited. Yet it accomplishes three things:

1. It provides a sharp look at the duties of the Prime Minister and draws the conclusion that it was his duty to convene Ministerial meetings and that failing to do so amounts to criminal negligence.

2. It shows that duty can depend on the knowledge and understanding of the person to whom it is ascribed. Based on epistemic assumptions about the Prime Minister it makes his personal qualities is key to his duty-and thus to criminal accountability.

3. It combines a narrow legal approach with a broader moral assessment by placing the violation of ministerial duty in the context of a more general governmental failure to form policy in a coordinated attempt to provide a proper response to events evolving in the months preceding the crisis.

But the indictment, verdict and trial also have serious shortcomings because of which the fairness of the whole affair becomes questionable and its political guidance limited:

1. There is reason to believe that even though a majority of MP's supported the indictment of the former Prime Minister, only a minority actually preferred prosecuting him alone to prosecuting no one.

2. The verdict ignores arguments contradicting its epistemic assumptions. It is generally acknowledged that for a long time before the crisis it was commonly believed in Iceland that the extraordinary success of the banks was due to brilliant leadership. This may have blinded the Prime Minister to the seriousness of the crisis until it was too late.

All things considered it is difficult to produce a single conclusion or assessment-let alone a moral assessment of the whole affair. It ended in an embarrassment: Instead of a general acknowledgment that the court's conclusion answered an important question about accountability it has since been a far more vocal opinion in Iceland that the trial was a mockery of justice and that the treatment of the former Prime Minister was deeply unfair. Yet, as I have argued in this paper, the guilty verdict of Geir Haarde provides an excellent example of how responsibility can be addressed after governmental failure: This case should be carefully studied by those who seek to understand the implications of ministerial accountability when gross failures occur without criminal intent. As I have argued one should be skeptical about convicting a government minister (or former minister) on legal duty alone, and an accountability mechanism must of course not facilitate criminalizing political 
behavior. But as I have shown these objections do not apply to the verdict passed by the majority of the Icelandic court of impeachment, which found a way to convict a Prime minister for his violation of a legal duty on the background of a more general failure to mobilize the available resources to protect his country from disaster.

\section{DATA AVAILABILITY STATEMENT}

The original contributions presented in the study are included in the article/supplementary material, further inquiries can be directed to the corresponding author/s.

\section{REFERENCES}

Act on Ministerial Accountability (1963). No. 419 February. Available online at: https://www.sakal.is/media/skjol/Act-on-Ministerial-Accountability.pdf. accessed 18 March 2021. See Icelandic original, Lög um ráðherraábyrgð 4/1963 https://www.althingi.is/lagas/nuna/1963004.html (accessed March 18, 2021).

Act on the Court of Impeachment (1963). No. 319 February. Available online at: https://sakal.is/media/skjol/Act-on-the-Court-of-Impeachment.pdf (accessed March 18, 2021).

Alpingismannatal (n.d.). Björgvin G. Sigurðsson - pingsetutímabil og embœtti. Available online at: https://www.althingi.is/altext/cv/is/thingseta/?nfaerslunr= 653 (accessed October 12, 2019).

Alvarleg ákæra sem erfitt er að refsa fyrir (2012). Morgunblaðið 24 April, p. 17.

Árnason, L. (2012). “Geir sá um sig sjálfur” (personal blog) DV. Available online at: http://wayback.vefsafn.is/wayback/20121205024150/http://www.dv. is/blogg/lydur-arnason/2012/4/24/geir-sa-um-sig-sjalfur/ (accessed October 30, 2019).

Atkvæðagreiðslur priðjudaginn (2010). Available online at: https://www.althingi. is/thingstorf/thingmalin/atkvaedagreidslur/?btim $=2010-09-28 \$+\$ 16: 09: 16 \&$ etim $=2010-09-28 \$+\$ 17: 14: 54$ (accessed October 30, 2019).

Bergmann, E. (2014). Iceland and the International Financial Crisis. Boom, Bust and Recovery. Basingstoke: Palgrave Macmillan.

Blöndal, K. (2010) "Í leit að lausnum” Sunnudagsmogginn 18 April, p. 4.

Bovens, M, Goodin, R. E., and Schillemans, T. (ed.). (2014). "Public accountability," in The Oxford Handbook of Public Accountability (New York, NY: Oxford University Press), 1-20.

Bragadóttir, R. (2017). "Criminal law and the financial crisis: the proceedings against Iceland's Former Prime Minister Geir H. Haarde," in Criminal Liability of Political Decision-Makers. A Comparative Perspective, ed F. Zimmermann (Cham: Springer International Publishing), 357-368.

Cassam, Q. (2019). Vices of the Mind: From the Intellectual to the Political. New York, NY: Oxford University Press.

Code of conduct for government ministers (2011). Government of Iceland. Current version (in Icelandic). Available online at: https://www.stjornarradid. is/rikisstjorn/sidareglur-radherra/ (accessed September 30, 2020). An English translation of the first version of the code is available online at: https://web. archive.org/web/20170412111807/www.government.is/government/code- ofconduct/ (accessed September 30, 2020).

Constitution of the Republic of Iceland (1944). Government of Iceland. Available online at: https://www.government.is/topics/governance-and-nationalsymbols/constitution/ (accessed November 16, 2020).

Deliberative Poll: Public Consultation on the Revision of the Icelandic Constitution (2020). University of Iceland, Social Science Research Institute. Available online at: https://felagsvisindastofnun-verkefni.hi.is/wp-content/ uploads/2020/06/Endurskodun_stjornarskrar.pdf (accessed March 18, 2021).

ECHR 357 (2017). Trial of former Icelandic Prime Minister for negligence in 2008 bank crisis was not unfair. Press Release, 357, 23 November. Available online at: https://hudoc.echr.coe.int/eng-presitemid:003-5924550-7565750 (accessed October 30, 2019).

ECHR 66847/12 (2018). Case of Haarde v. Iceland App no 66847/12 (23 February). Fricker, M. (2007). Epistemic Injustice. Oxford: Oxford University Press.

\section{AUTHOR CONTRIBUTIONS}

The author confirms being the sole contributor of this work and has approved it for publication.

\section{FUNDING}

The research conducted for this article was supported by the University of Iceland research fund and by EDDA Research Center via Reimagining Norden in an Evolving World, a research hub (ReNEW), a NordForsk funded project (Project number 86036).

Frumvarp til laga um ráđherraábyrgð (1962). 4. mál, 83. Löggjafarping 1962. Available online at: https://www.althingi.is/altext/83/s/pdf/0004.pdf (accessed October 30, 2019).

Gissurarson, H. H. (2012). A Prime Minister in the Dock. The Wall Street Journal. Available online at: https://www.wsj.com/articles/ SB10001424052702303592404577362002741198304 (accessed September 30, 2020).

Grímsson, Ó. R. (2006). "Icelandic ventures: can the success continue," in $A$ Speech at The Kaupthing Seminar Helsinki. Available online at: http://wayback. vefsafn.is/wayback/20091118075237/http://www.forseti.is/media/files/06.05. 24.Helsinki.Conference.pdf (accessed October 30, 2020).

Gunnarsson, T. (2012). Stórmerkur dómur! Fréttablaðið, 14.

Haarde, G. (2008). Address to the Nation, RUVV 6 October. Available online at: https://www.youtube.com/watch?v=pQA2kK_MFjA (accessed November 19, 2020).

Hauksson, J. (2010). Saksókn gegn ráðherrum í uppnámi. DV, 13.

Hilliard, N., Kovras, I., and Loizides, N. (2021). The perils of accountability after crisis: ambiguity, policy legacies, and value trade-offs. Cambridge Rev. Int. Affairs 34, 85-104. doi: 10.1080/09557571.2019.17 10827

Hilmarsson, H. P. (2013). Small states and big banks - the case of Iceland. Baltic J. Econ. 13, 31-48. doi: 10.1080/1406099X.2013.10840524

Hjalmarsson, R., and Kovras, I. (2017). Should We Prosecute Political Leaders After a Crisis? Lessons From Iceland. LSE blog. Available online at: https://blogs.lse ac.uk/europpblog/2017/12/06/should-we-prosecute-political-leaders-after-acrisis-lessons-from-iceland/ (accessed September 29, 2020).

Hrakför pjóðkjörinna ákærenda (2012). Morgunblaðið (unsigned lead article) 24 April, p. 20.

IRR13110314/3.11 (2011). Althingi v Geir Hilmar Haarde. Decision of the Court of Impeachment No 3/2011 3 October. The English translation is available online at: https://reiknistofnun-my.sharepoint.com/:f:/g/personal/jonolafs hi_is/Ep1IgEsWVAFJs_vnJWDRTWQBCwYcTdbMB3-yCcSQDv1yWQ?e= 4fQJB9 (accessed March 18, 2021).

IRR13110314/3.11 (2012). Althingi v Geir Hilmar Haarde. Judgment of the Court of Impeachment No 3/2011 23 April. The English translation is available online at: https://reiknistofnun-my.sharepoint.com/:f:/g/personal/jonolafs_hi_is/ Ep1IgEsWVAFJs_vnJWDRTWQBCwYcTdbMB3-yCcSQDv1yWQ?e=4fQJB9 (accessed March 18, 2021).

Johnsen, G. (2015). Bringing down the Banking System: Lessons From Iceland. Basingstoke: Palgrave Macmillan.

Jökulsson, I. (2010). “Kvein hrunverjanna.” DV, 28.

Mishkin, F., and Herbertsson, T.P. (2006). Financial Stability in Iceland. Reykjavík: Icelandic Chamber of Commerce, 36. Available online at: https://www.stjornarradid.is/media/utanrikisraduneyti-media/media/ Raedurogerindi/Financial_Stability_in_Iceland.pdf (accessed September 29, 2020).

Mulgan, R. G. (2003). Holding Power to Account: Accountability in Modern Democracies. New York, NY: Palgrave Macmillan.

Ógeðfelld afgreiðsla (2010). Morgunblaðið, 16.

Omtzigt, P. (rapporteur) (2013). Keeping Political and Criminal Responsibility Separate. Committee on Legal Affairs and Human Rights, doc. 13214. Available 
online at: https://www.ecoi.net/en/file/local/1224555/1226_1369820122_ xrefview.pdf (accessed October 30, 2019).

Pálsson, P. (2010). “Eftirmálin.” Fréttablaðið, 12.

Parliamentary Resolution (2010). 30/138 On Commencing Legal Proceedings Against a Minister Available online at: https://www.sakal.is/media/skjol/ Parlimentary-resolution.pdf (accessed November 20, 2020). The Icelandic original is available on Althingi's site: https://www.althingi.is/altext/138/s/1538. html (accessed October 30, 2019).

Patel, A. C., De Greiff, P., and Waldorf, L. (eds.). (2009). Disarming the Past: Transitional Justice and Ex-Combatants. New York, NY: Social Science Research Council.

Pólitískur pefur af dómnum (2012). Morgunblaðið, 4.

Portes, M., and Baldursson, F. M. (2007). The Internationalisation of Iceland's Financial Sector. Reykajavík: Icelandic CHmaber of Commerce. Available online at: https://www.vi.is/files/útgáfa/skýrslur/2007_11_21_theinternationalisation-of-icelands-financial-sector.pdf (accessed September 29, 2020).

Rannsóknarnefnd Alpingis (2010). Aðdragandi og orsakir falls íslensku bankanna 2008, Vol. 1-8. Reykjavík: Alpingi. Available in Icelandic at https://www.rna.is/ eldri-nefndir/addragandi-og-orsakir-falls-islensku-bankanna-2008/skyrslanefndarinnar/(accessed September 30, 2020).

Reykjavíkurbréf: Mál lagt í dóm (2012). Sunnudagsmogginn, 22-23.

Reynisson, J. T. (2012). Lærdómur af hroka Geirs. DV, 16.

Saksóknari Alpingis (2011). Ákara. Available online at: http://www. sakal.is/media/skjol/Akaera-10.5.2011.pdf (accessed October 30, 2019).

Sigurðardóttir, J. (2012a). Í kjölfar dóms Landsdóms. Fréttablaðið, 13.

Sigurðardóttir, S. (2012b). Pólitísk réttarhöld - pólitískur farsi. Morgunblaðið, 25.

Skýrsla pingmannanefndar til að fjalla um skýrslu rannsóknarnefndar Alpingis (2010). Pskj. 1501. Available online at: https://www.althingi.is/altext/138/s/ 1501.html (accessed September 29, 2020).

Special Investigation Commission (2010a). Summary of the Report's Main Conclusions (Partial English Translation of Volume 1 of the Report). Available online at: https://www.rna.is/media/skjol/RNAvefKafli2Enska.pdf (accessed September 30, 2020).
Special Investigation Commission (2010b). Causes of the Collapse of the Icelandic Banks - Responsibility, Mistakes and Negligence (Partial English Translation of Volume 7 of the Report). Available online at: https://www.rna.is/media/skjol/ RNAvefurKafli21Enska.pdf (accessed November 20, 2020).

Tillaga til pingsályktunar um málshöfðun gegn ráðherrum (2010). Available online at: https://www.althingi.is/altext/138/s/1502.html (accessed October 30, 2019). Recordings and transcripts of the Parliamentary session where the resolutions were voted on can be found here: https://www.althingi.is/altext/ 138/09/128160916.sgml (accessed October 30, 2019).

US Department of Justice (n.d.). Public Integrity Section annual reports to Congress. Available online at: https://www.justice.gov/criminal/pin (accessed October 30, 2019).

Zimmermann, F. (2017a). "A comparative analysis of criminal laws protecting public budgets: can bad political decisions be criminalised?" in Criminal Liability of Political Decision-Makers. A Comparative Perspective, ed F. Zimmermann (Cham: Springer International Publishing), 255-264.

Zimmermann, F. (ed.). (2017b). Criminal Liability of Political Decision-Makers. A Comparative Perspective. Cham: Springer International Publishing.

pjóðarpúls Gallups (2010). Margir vilja draga ráðherra til ábyrgðar. Avaialble online at: https://cdn.gallup.is/media/documents/thodarpuls_2010_09.pdf (accessed Spetmber 30, 2020).

pjóðarpúls Gallups (2012). Available online at: https://cdn.gallup.is/media/ documents/thjodarpuls_2012_02_landsdomsmalid.pdf (accessed September $30,2020)$.

Conflict of Interest: The author declares that the research was conducted in the absence of any commercial or financial relationships that could be construed as a potential conflict of interest.

Copyright (c) 2021 Ólafsson. This is an open-access article distributed under the terms of the Creative Commons Attribution License (CC BY). The use, distribution or reproduction in other forums is permitted, provided the original author(s) and the copyright owner(s) are credited and that the original publication in this journal is cited, in accordance with accepted academic practice. No use, distribution or reproduction is permitted which does not comply with these terms. 